University of Nebraska - Lincoln

DigitalCommons@University of Nebraska - Lincoln

2-19-2001

\title{
COMPARISON OF CONVENTIONAL AND TWO-STAGE REVERSIBLE FLOW, STATIC-BED BIODENITRIFICATION REACTORS
}

\author{
Bryan L. Woodbury \\ USDA-ARS, bryan.woodbury@ars.usda.gov \\ Mohamed F. Dahab \\ University of Nebraska-Lincoln, mdahab1@unl.edu
}

Follow this and additional works at: https://digitalcommons.unl.edu/animalscifacpub

Part of the Animal Sciences Commons

\begin{abstract}
Woodbury, Bryan L. and Dahab, Mohamed F., "COMPARISON OF CONVENTIONAL AND TWO-STAGE REVERSIBLE FLOW, STATIC-BED BIODENITRIFICATION REACTORS" (2001). Faculty Papers and Publications in Animal Science. 3.

https://digitalcommons.unl.edu/animalscifacpub/3
\end{abstract}

This Article is brought to you for free and open access by the Animal Science Department at DigitalCommons@University of Nebraska - Lincoln. It has been accepted for inclusion in Faculty Papers and Publications in Animal Science by an authorized administrator of DigitalCommons@University of Nebraska - Lincoln. 


\title{
PERGAMON
}

www.elsevier.com/locate/watres

\section{COMPARISON OF CONVENTIONAL AND TWO-STAGE REVERSIBLE FLOW, STATIC-BED BIODENITRIFICATION REACTORS}

\author{
BRYAN L. WOODBURY ${ }^{1 *}$ and MOHAMED F. DAHAB ${ }^{2}$ \\ ${ }^{1}$ USDA Agriculture Research Service, US Meat Animal Research Center, Clay Center, NE 68933, USA \\ and ${ }^{2}$ Department of Civil Engineering, University of Nebraska-Lincoln, Lincoln, NE 68588-0531, USA
}

(First received 1 April 1999; accepted in revised form 1 July 2000)

\begin{abstract}
This paper compares the operation of a traditional single-stage system with a two-stage, reversible flow biodenitrification system for removing nitrates from drinking water. The purpose of this study was to investigate the ability of these two-stage systems to remove nitrate and residual organics from treated water as compared to single-stage units. In the reversible flow system, the second-stage (i.e. follow) reactor is operated in series with the first-stage (i.e. lead) reactor. After a given period of operation, the flow regime is reversed so that the follow reactor becomes the lead one and vice versa. The active solids remaining in the follow reactor (previously the lead one) are capable of removing residual soluble organics and nitrates to levels below the concentrations provided by single-stage units particularly at HRTs as low as $0.5 \mathrm{~h}$. Nitrate-nitrogen removal efficiency improved slightly from 98 to $99.5 \%$ for the single- and twostage systems, respectively. Most notably, reversible flow reactors were found to reduce long-term effluent residual organics concentrations with an average of approximately $1 / 3$ that of the single-stage system. Also the reversible flow system, with its design redundancy, demonstrated the ability to receive extreme shock loads with no sustained loss of treatment efficiency. (C) 2001 Elsevier Science Ltd. All rights reserved
\end{abstract}

Key words—biodenitrification, fixed-film, static-bed, nitrate, nitrogen, reversible-flow, groundwater contamination

\section{INTRODUCTION}

Nitrate concentrations in groundwater have been increasing over the years in many areas in the United States. This contamination has steadily increased past the maximum contaminant limit (MCL) of $10 \mathrm{mg} \mathrm{NO}-\mathrm{NL}^{-1}$ established by the US Environmental Protection Agency (US EPA, 1987). In some locations in Nebraska, nitrate concentrations have reached levels that are several times the MCL (Dahab and Lee, 1988). Synthetic fertilizer application appears to be the largest source of groundwater nitrate contamination in the US, most of which is applied as anhydrous ammonia, ammonium salts, and urea. In the US, Nebraska ranks second among all states in nitrogen use and with a combination of a large irrigated area and sandy soils, groundwater nitrate contamination is common. The US EPA data show that nitrate contamination in Nebraska reached or exceeded $14 \mathrm{mg} \mathrm{NO}_{3}^{-}-\mathrm{N} \mathrm{L}^{-1}$ in $20 \%$ of surveyed wells (Bouchard et al., 1992).

\footnotetext{
*Author to whom all correspondence should be addressed.
}

\section{Health effects of nitrates}

In the US, nitrates in drinking water are regulated by the US EPA based on preventing methemoglobinemia in infants. Infants less than six months of age are considered the most susceptible. Methemoglobinemia is a condition in which nitrite reacts with hemoglobin to form methemoglobin which impairs the oxygen carrying capacity of the blood. Nitrites also have been found to react with amines and amides to form nitrosamines and nitrosoamides, which are known carcinogens in many organs of rodents. Specifically, nitrosamines induce tumors of the liver, kidney, esophagus, oral and nasal cavities, lung, trachea, urinary bladder, pancreas, and thyroid in rodents (Mirvish, 1991). Nitrosamides induce tumors of the stomach, intestine, brain, nervous system, bone and skin, acute leukemia, and $\mathrm{T}$ and $\mathrm{B}$ cell lymphoma. There is no other group of carcinogens that can produce such a wide variety of tumors (Mirvish, 1991).

\section{Nitrate removal using biodenitrification}

Biodenitrification is a very adaptable process for removing nitrate from water supplies. Upflow anaerobic sludge blanket (UASB), sequencing batch 
(SBR), and fluidized-bed reactors have been used successfully for removing nitrate-nitrogen from water even when concentrations are as high as $700-900 \mathrm{mg}$ $\mathrm{NO}_{3}^{-}-\mathrm{NL}^{-1}$ (van der Hoek and Klapwijk, 1987; Clifford and Liu, 1993; Mihaltz et al., 1997). These reactor designs have an advantage over static-bed processes in that better biomass control can be maintained within the reactors. Biomass control is particularly important when attempting to operate biodenitrification reactors at high loading rates. However, the improved biomass control results in substantial treatment of the reactor effluent to remove the imparted soluble organics and suspended solids.

Fixed-film, static-bed biodenitrification reactors have been proven to effectively remove nitrate for water. Blowes et al. (1994) used static-bed, fixed-film reactors containing coarse sand as the solid support media and waste cellulose as the carbon source to denitrify agricultural runoff water. The system effectively removed $3-6 \mathrm{mg} \mathrm{NO}_{3}^{-}-\mathrm{N} \mathrm{L}^{-1}$ from up to $60 \mathrm{~L}$ of water per day. Hunter et al. (1997) used a similar sandy aquifer material as the support media and aquifer water contaminated with up to $16 \mathrm{NO}_{3}^{-}-$ $\mathrm{NL}^{-1}$. The carbon source for denitrification was a sparingly soluble vegetable oil which provided adequate nitrate removal for extended periods from a single carbon source injection. However, when the flow rates were increased with the corresponding increase in oil addition, flow problems resulted as reactor back-pressure increased.

Dahab and Lee (1988) used $1.2 \mathrm{~m}$ tall columns for bench scale models to treat water with $100 \mathrm{mg} \mathrm{NO}_{3}^{-}-$ $\mathrm{N} \mathrm{L}^{-1}$ using acetic acid as the external carbon source. A carbon to nitrogen ratio $(\mathrm{C}: \mathrm{N})$ of 1.5 was found optimal for denitrification in that research. Nitrate removal efficiencies of nearly $100 \%$ were reported throughout the entire study. Dahab and Sirigina (1994) reported that the use of fixed-film, static-bed biodenitrification reactors with an influent concentration of $50 \mathrm{mg} \mathrm{NO}--\mathrm{NL}^{-1}$ resulted in a nitrate removal efficiency of about $100 \%$ throughout the experiments. The carbon to nitrogen ratio was $1: 1$ (using ethanol as the carbon source), and a hydraulic retention time of $2 \mathrm{~h}$ was used in the experiments. Previous research on biodenitrification indicates that high soluble carbon concentrations can be expected in the effluent from single-stage upflow reactors (Dahab and Sirigina, 1994; Dahab and Lee, 1988). To overcome this problem, reversible flow, static-bed biodenitrification reactors were investigated in this research.

\section{Reversible flow, fixed-film reactors}

The two-stage, reversible flow system is comprised of two equally sized reactors that are operated in series. The contaminated water is pumped into the first (lead) reactor in upflow mode. The lead reactor effluent then becomes the influent of the second (follow) reactor which is also operated in upflow mode. To maintain biomass stability in the first reactor, the flow regime is periodically reversed and the influent feed solution is transferred from the lead to the follow reactor. In this manner, the follow reactor is maintained in or near an endogenous respiration mode thus ensuring effective residual substrate removal in this unit. Thus, the two-stage, reversible flow reactor system would produce considerably lower organic concentrations in reactor effluent than traditional single-stage systems operating at the same organic loading.

The reversible flow concept appears suitable to a variety of fixed film, static-bed reactor systems including denitrification and anaerobic systems. Siddique and Young (1995) reported that a nitrate removal efficiency of more than $98 \%$ was achieved when using a two-stage, reversible flow system for nitrate removal from water. The system was operated at a hydraulic retention time (HRT) of $12 \mathrm{~h}, 30 \mathrm{mg}$ $\mathrm{NO}_{3}^{-}-\mathrm{N} \mathrm{L}^{-1}$ and a $\mathrm{C}: \mathrm{N}$ ratio of 0.92 using methanol as the carbon source. An efficiency of more than $95 \%$ was obtained when the HRT was $6 \mathrm{~h}$. However, these HRTs translate into large capital expenditures to construct reactor volumes necessary to satisfy most treatment objectives.

The ability of the reversible flow system to consistently discharge relatively low effluent COD concentrations was demonstrated by Howerton and Young (1987). They reported in their research with anaerobic filters that the combined overall COD removal efficiency was in excess of $98 \%$. The effluent COD was decreased from $12,000 \mathrm{mg} \mathrm{L}^{-1}$ in the lead reactor influent to about $500 \mathrm{mg} \mathrm{L}^{-1}$, and to less than $90 \mathrm{mg} \mathrm{L}^{-1}$ in follow reactor effluent. This overall performance was substantially greater than the removal efficiencies experienced by traditional single-stage units operating at the same system loading and influent concentration.

\section{OBJECTIVES}

The specific objectives of this study were to (1) compare the performance of two-stage, reversible flow system with a traditional single-stage system in reducing nitrates, nitrites, and residual carbon concentrations when operated at low hydraulic retention times; and (2) evaluate the individual responses of the two reactors immediately following flow reversals, and to observe steady-state performance characteristics resulting from the reversible flow operation.

\section{METHODOLOGY}

The experimental system consisted of three static-bed, fixed-film reactors; two of them were connected in series and operated as a two-stage, reversible flow system, and the third reactor was operated as a traditional single-stage system. The reversible flow system consisted of two reactors connected in series where the effluent of the lead reactor 


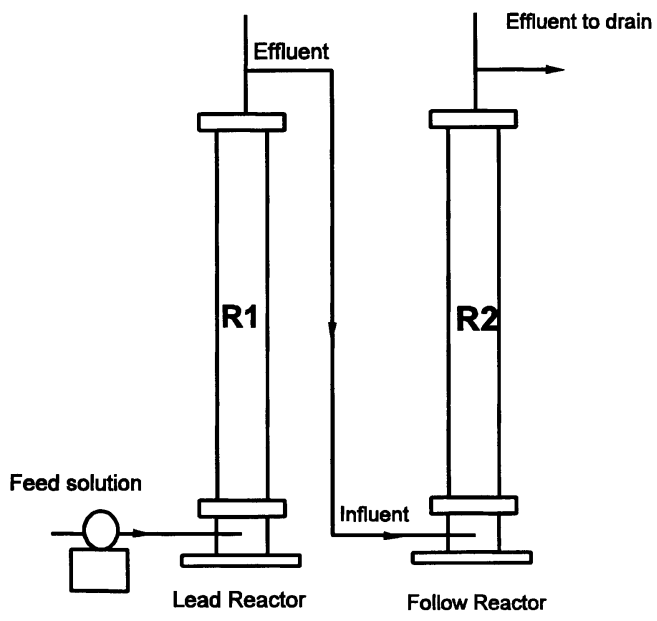

Flow Cycle One
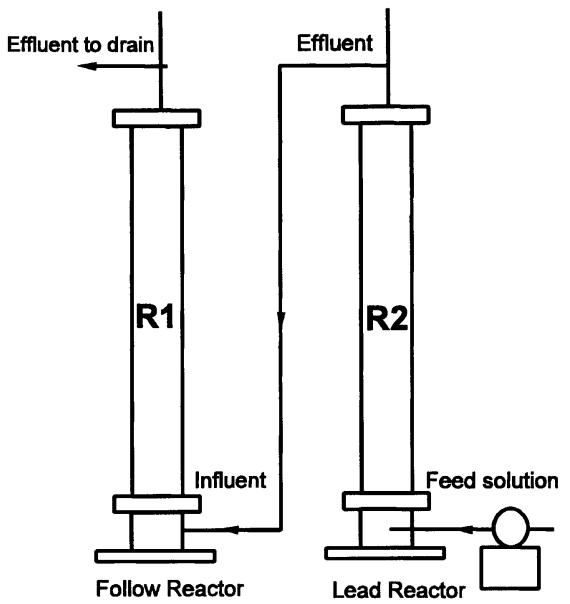

Fig. 1. Schematic diagram of the reversible flow reactor process. Note the two distinct flow cycles.

became the feed solution of the follow reactor. The reactors of both systems were static-bed, fixed-film and were operated under upflow conditions. The reversible flow system is characterized with two distinct flow cycles (Fig. 1). The reactors were constructed using plexiglass tubing with an inside diameter of $70 \mathrm{~mm}$ and a height of $460 \mathrm{~mm}$ (Fig. 2). The total volume of the two-stage system was twice that of the single-stage system. To maintain the consistent retention time between the two systems, the flow rates of the two-stage reactor system were twice the singlestage system. Dispersion rings, designed to limit the preferential flow of the feed solution along the reactor wall, were placed at approximately 150 and $300 \mathrm{~mm}$, respectively, from the bottom of the reactor body. The reactors were packed with cylindrical Pall rings with an average diameter and length of $16 \mathrm{~mm}$; a specific surface area of $4.4 \mathrm{~mm}^{2} \mathrm{~mm}^{-3}$; and an average weight of $0.49 \mathrm{~g} \mathrm{ring}^{-1}$. The Pall rings were made of polypropylene, with a random pack void fraction of $89 \%$. Variable-speed peristaltic pump systems were used to deliver feed water to reactors at a range of flow rates depending on the study phase (Table 1). Feed solution was mixed and stored in covered $200 \mathrm{~L}$ plastic tanks. Feed solution was prepared with known concentrations of nitrate, COD (carbon), and other trace mineral constituents essential to denitrifier growth. Potassium nitrate was supplied at a concentration of $50 \mathrm{mg} \mathrm{NO}-$ $\mathrm{NL}^{-1}$ throughout the investigation. The carbon source was ethanol and was supplied at a concentration of $50 \mathrm{mg}$ carbon $\mathrm{L}^{-1}$. Monobasic and dibasic potassium phosphates were used as a buffer system to help maintain the feed water at approximately $\mathrm{pH} 7.0$ and also as a phosphorus source for microorganisms. Sodium sulfite $\left(20 \mathrm{mg} \mathrm{L}^{-1}\right)$ and cobalt chloride (approx. $0.25 \mu \mathrm{g} \mathrm{L}^{-1}$ ) were added to react with the feed solution dissolved oxygen to ensure that anoxic conditions existed in the system. The feed water tanks were covered to minimize oxygen exchange from the atmosphere with the anoxic feed solution. The feed water composition was intended to simulate groundwater and the entire investigation was carried out at a relatively constant ambient temperature of about $20^{\circ} \mathrm{C}$. The reactors' removal efficiencies were evaluated at different HRTs and flow cycle reversals. The study was divided into six phases as summarized in Table 1. The start-up phase was intended to establish sufficient biomass in each reactor before connecting the reactors in series.

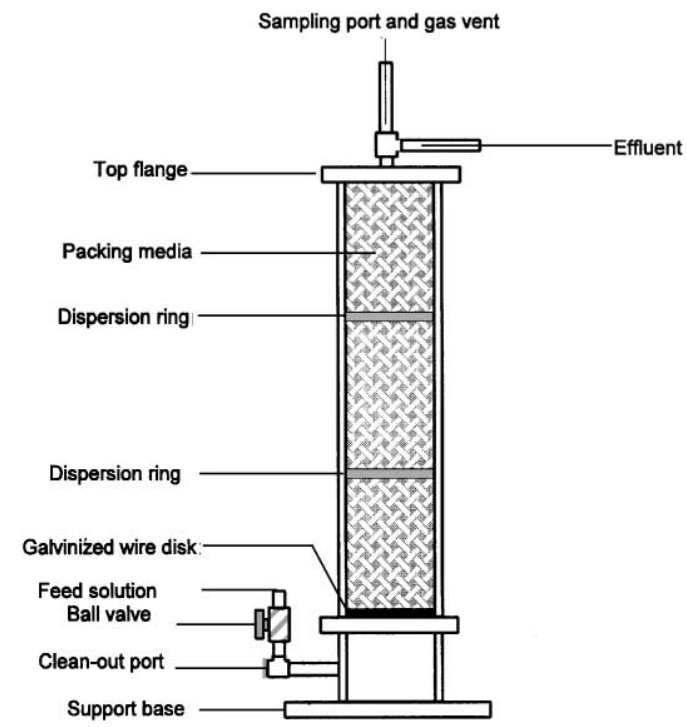

Fig. 2. Schematic diagram of the upflow static-bed biodenitrification reactor.

The reactors were seeded using effluent collected from the primary clarifier $\left(2 \mathrm{~L} \mathrm{reactor}^{-1}\right)$ of a municipal wastewater treatment facility. For the purposes of this study, primary effluent was considered to be an effective and rapid seed source. Next, the reactors were supplied with the described feed water at a constant rate at a HRT of $36 \mathrm{~h}$ to avoid shock loading to the bacterial seed and washout of denitrifiers from the reactors. The start-up phase was designed to accumulate biomass in the reactors in order to ensure an adequate bacterial growth and subsequent performance of the reactor systems. This phase lasted approximately three weeks.

Effluent water samples were collected from each reactor approximately every other day. Each sample was filtered using a glass fiber filter with a $1.5 \mu \mathrm{m}$ retention. The filtered sample nitrate-nitrogen analysis followed procedures outlined in Methods 8039 and 8171 of the Hach Water Analysis Handbook (Hach, 1992). The nitrite-nitrogen analysis 
Table 1. Operational sequence and HRT values used during the study

\begin{tabular}{|c|c|c|c|c|c|c|c|}
\hline \multirow[t]{2}{*}{ Phase } & \multirow{2}{*}{$\begin{array}{l}\text { Hydraulic } \\
\text { retention time } \\
\text { (HRT) (h) }\end{array}$} & \multicolumn{3}{|c|}{ Number of days in operation } & \multirow[t]{2}{*}{ Lead reactor } & \multirow[t]{2}{*}{ Follow reactor } & \multirow[t]{2}{*}{ Single-stage reactor } \\
\hline & & Total & Cycle 1 & Cycle 2 & & & \\
\hline 1 & 24 & 14 & 14 & \multirow[t]{2}{*}{- no- } & R1 & R2 & R3 \\
\hline \multirow[t]{2}{*}{2} & 12 & 42 & 21 & & R1 & $\mathrm{R} 2$ & R3 \\
\hline & & & & \multirow[t]{2}{*}{21} & R2 & R1 & \\
\hline \multirow[t]{2}{*}{3} & 6 & 28 & 14 & & R2 & R1 & R3 \\
\hline & & & & \multirow[t]{2}{*}{14} & R1 & R2 & \\
\hline \multirow[t]{2}{*}{4} & 3 & 41 & 21 & & R1 & R2 & R3 \\
\hline & & & & \multirow{2}{*}{20} & R2 & R1 & \\
\hline \multirow[t]{2}{*}{5} & 1 & 61 & 32 & & R2 & R1 & R3 \\
\hline & & & & \multirow[t]{2}{*}{29} & R1 & R2 & \\
\hline \multirow[t]{2}{*}{6} & 0.5 & 32 & 16 & & R1 & R2 & R3 \\
\hline & & & & 16 & R2 & R1 & \\
\hline
\end{tabular}

Note: R1= Reactor 1, R2= Reactor 2, R3= Reactor 3 (see Fig. 1).

Table 2. Phase-average nitrate removal efficiencies and concentrations of the single- and two-stage reactor system for flow cycles 1 and $2^{\dagger}$

\begin{tabular}{|c|c|c|c|c|c|c|c|c|c|c|c|c|c|}
\hline \multirow[b]{2}{*}{ Phase } & \multirow[b]{2}{*}{ HRT } & \multicolumn{6}{|c|}{ Flow cycle 1} & \multicolumn{6}{|c|}{ Flow cycle 2} \\
\hline & & $(\%)$ & $\begin{array}{l}\text { Lead } \\
\qquad\left(\mathrm{mg} \mathrm{L}^{-1}\right)\end{array}$ & $(\%)$ & $\begin{array}{l}\text { ollow } \\
\left(\mathrm{mg} \mathrm{L}^{-1}\right)\end{array}$ & $\begin{array}{r}\mathrm{Si} \\
(\%)\end{array}$ & $\begin{array}{l}\text { le-stage } \\
\left(\mathrm{mg} \mathrm{L}^{-1}\right)\end{array}$ & $(\%)$ & $\begin{array}{l}\text { Lead } \\
\qquad\left(\mathrm{mg} \mathrm{L}^{-1}\right)\end{array}$ & $(\%)$ & $\begin{array}{l}\text { ollow } \\
\left(\mathrm{mg} \mathrm{L}^{-1}\right)\end{array}$ & $\begin{array}{l}\text { Sir } \\
(\%)\end{array}$ & $\begin{array}{l}\text { le-stage } \\
\left(\mathrm{mg} \mathrm{L}^{-1}\right)\end{array}$ \\
\hline 1 & 24 & 96 & 1.8 & 99 & 0.7 & 96 & 1.9 & NA & NA & NA & NA & NA & NA \\
\hline 2 & 12 & 98 & 1.0 & 100 & 0.2 & 97 & 1.4 & 91 & 4.3 & 97 & 1.5 & 99 & 0.7 \\
\hline 3 & 6 & 99 & 0.5 & 100 & 0.2 & 99 & 0.3 & 99 & 0.5 & 100 & 0.2 & 99 & 0.3 \\
\hline 4 & 3 & 99 & 0.5 & 100 & 0.2 & 99 & 0.5 & 99 & 0.5 & 100 & 0.2 & 100 & 0.2 \\
\hline 5 & 1 & 99 & 0.7 & 99 & 0.3 & 99 & 0.6 & 99 & 0.6 & 100 & 0.2 & 99 & 0.3 \\
\hline 6 & 0.5 & 98 & 0.9 & 99 & 0.3 & 98 & 0.9 & 98 & 1.0 & 99 & 0.6 & 98 & 0.8 \\
\hline
\end{tabular}

${ }^{\dagger} \mathrm{HRT}=$ hydraulic retention time based on an empty-bed volume with a porosity of $89 \%$.

followed procedures outlined in Method 8507 of the Hach Water Analysis Handbook (Hach, 1992). The samples were also analyzed for soluble chemical oxygen demand (SCOD) following procedures outlined in Method 5220 in Standard Methods for the Examination of Water and Wastewater (APHA, 1992).

\section{RESULTS}

Phases 1,2 and 3 were operated at 24, 12 and $6 \mathrm{~h}$ HRT, respectively (Table 1). During Phase 1 the reactors were fed at a constant flow rate for approximately 2 weeks. There was no flow reversal during this phase. Phase 2 was operated at a constant flow rate for 6 weeks with flow cycle reversal after 3 weeks. Phase 3 was operated for 4 weeks with flow cycle reversal after 2 weeks. The nitrate removal efficiency for all phases was always in excess of $95 \%$ in the single-stage system, and $97 \%$, or higher, in the reversible flow system (Table 2). The average removal efficiency of the two-stage system was consistent during all of these phases with the exception of flow cycle 2 of Phase 2 when the average nitrate concentrations of the lead and follow reactors were 4.3 and $1.5 \mathrm{mg} \mathrm{L}^{-1}$, respectively (Table 2). This was the first time since the start of the study that the follow reactor was placed in the lead position. Both lead and follow reactor biomass growth appeared to be minimal, particularly in the follow reactor, because of the minimal carbon loading at this relatively long retention time. The follow reactor did not appear to adjust to the radical change in the environmental conditions because of the limited biofilm growth. It should be noted that the singlestage reactor flow direction was not changed during the entire study and did not experience the periodic reductions in reactor efficiencies. All other HRT decreases and flow cycle reversals did not exhibit the effect on reactor efficiency as did the first flow reversal. However, these HRTs are probably impractical for economically sized reactor systems. The remainder of the discussion between the two systems will focus on Phases 4-6.

During the first flow cycle of Phase 4 (HRT of $3 \mathrm{~h}$ ) the nitrate removal efficiencies attained a mean of 99 , 100 and $99 \%$ in the lead, follow, and single-stage reactors, respectively (Table 2 ). These results indicated that reducing the HRT to $3 \mathrm{~h}$ had no deleterious effect on the nitrate removal efficiency. The effluent nitrate concentration from the singlestage system remained at an average of $0.2 \mathrm{mg} \mathrm{NO}_{3}^{-}-$ $\mathrm{NL}^{-1}$; more than $99 \%$ removal efficiency. In the follow reactor, the average effluent concentration was also $0.2 \mathrm{mg} \mathrm{NO}_{3}^{-}-\mathrm{N} \mathrm{L}^{-1}$, and it decreased to $0.1 \mathrm{mg}$ $\mathrm{NO}_{3}^{-}-\mathrm{N} \mathrm{L}^{-1}$ at the end of the phase (Fig. 3(A)). The reactors were operated for approximately 6 weeks during this phase.

The average nitrite concentrations were $0.2,0.1$, and $0.1 \mathrm{mg} \mathrm{NO}_{2}-\mathrm{N} \mathrm{L}^{-1}$ in the lead, follow, and singlestage reactors, respectively. No new trends were observed in nitrite concentrations during this phase (Fig. 3(B)). During Phases 1-3, the nitrite concentra- 

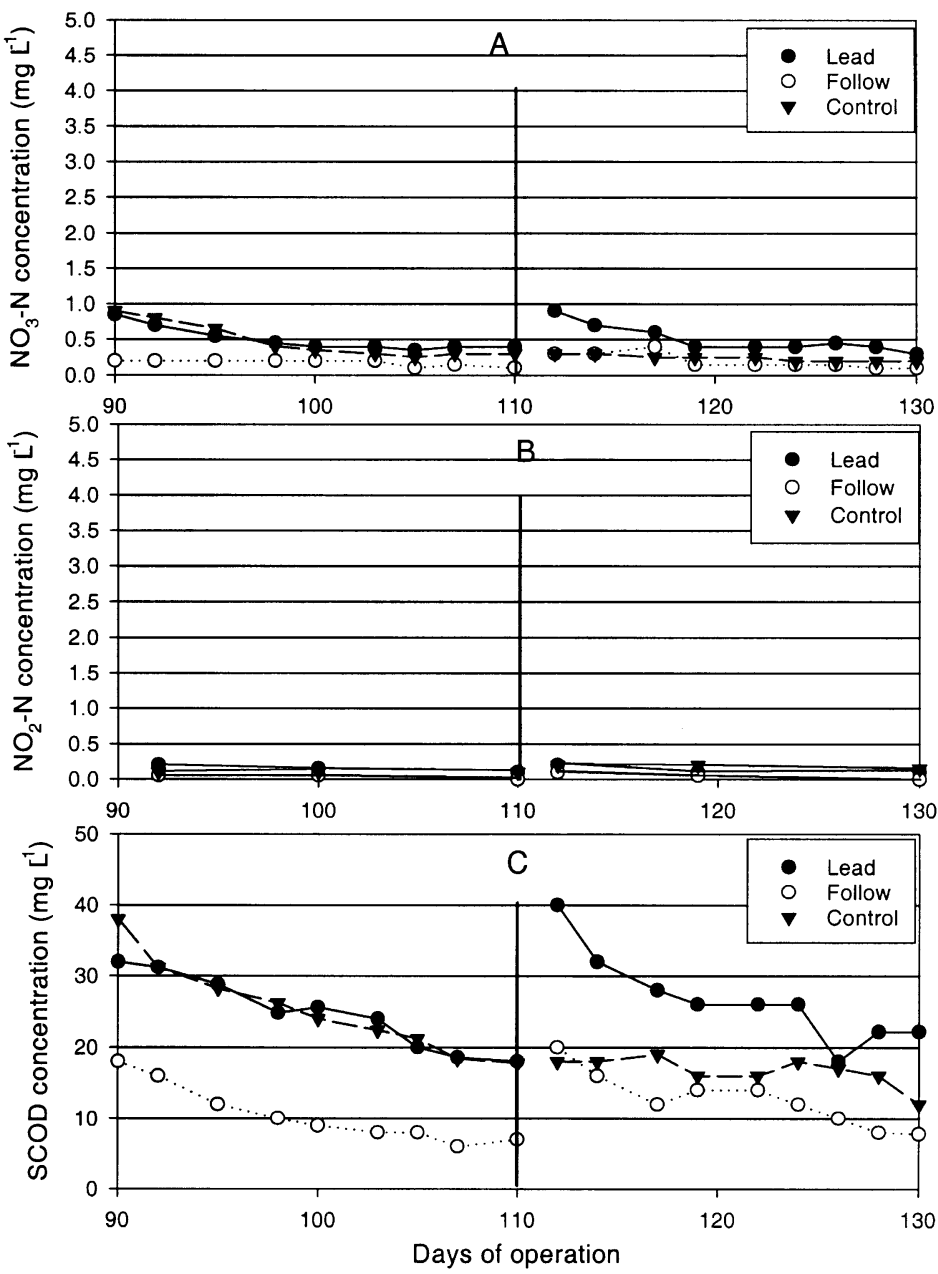

Fig. 3. Reactor effluent performance where $\mathrm{A}$ is the nitrate-nitrogen, $\mathrm{B}$ is the nitrite-nitrogen and $\mathrm{C}$ is the SCOD concentration during Phase 4. Note the flow reversal on day 110 of operation.

tions were almost all zero in all reactors and as a result, were not reported. However, the reduction of the HRT resulted in nearly consistent detection of nitrite-nitrogen in the effluent of both systems during Phase 4.

After reducing the HRT, the effluent SCOD increased initially to $32 \mathrm{mg} \mathrm{L}^{-1}$ in the lead reactor and $38 \mathrm{mg} \mathrm{L}^{-1}$ in the single-stage reactor. In both of these reactors, the effluent SCOD gradually decreased to $18 \mathrm{mg} \mathrm{L}^{-1}$ after 3 weeks of operation (Fig. 3(C)). The follow reactor started at approximately $20 \mathrm{mg} \mathrm{L}^{-1}$ and gradually decreased to $8 \mathrm{mg} \mathrm{L}^{-1}$. This trend was consistent for both flow cycles. The average effluent SCOD during flow cycle one in the lead, follow, and single-stage reactors were approximately 25,10 and $25 \mathrm{mg} \mathrm{L}^{-1}$, respectively. The gradual decreases in the effluent SCOD concentrations were attributed to the increase in reactor biomass as the flow period progressed. During flow cycle two of Phase 4, the effluent SCOD concentrations were 40 and $20 \mathrm{mg} \mathrm{L}^{-1}$ for the lead and follow reactors, respectively. The SCOD of each of these reactors gradually decreased to 22 and $8 \mathrm{mg} \mathrm{L}^{-1}$, respectively, while the single-stage system maintained effluent concentrations between 12 and $20 \mathrm{mg} \mathrm{L}^{-1}$ throughout the entire flow cycle. After 3 weeks of operation, the average effluent SCOD concentrations were 27,12 , and $17 \mathrm{mg} \mathrm{L}^{-1}$ for the lead, follow, and single-stage reactors, respectively.

Nitrate removal efficiencies of both systems were observed to be consistently above $98 \%$ in the three reactors. The effluent nitrate concentrations of each reactor were below $1.0 \mathrm{mg} \mathrm{L}^{-1}$ which is well below the MCL. The nitrite concentrations of each reactor were below $0.3 \mathrm{mg} \mathrm{L}^{-1}$ which is also well below the MCLG. This suggests that one could expect desirably low concentrations of nitrate and nitrite when operating at a HRT of $3 \mathrm{~h}$ or longer from either system. However, the reactor system performances in terms of SCOD removal were somewhat different. During the first flow cycle, the average SCOD was about $10 \mathrm{mg} \mathrm{L}^{-1}$ in the follow reactor and $25 \mathrm{mg} \mathrm{L}^{-1}$ 


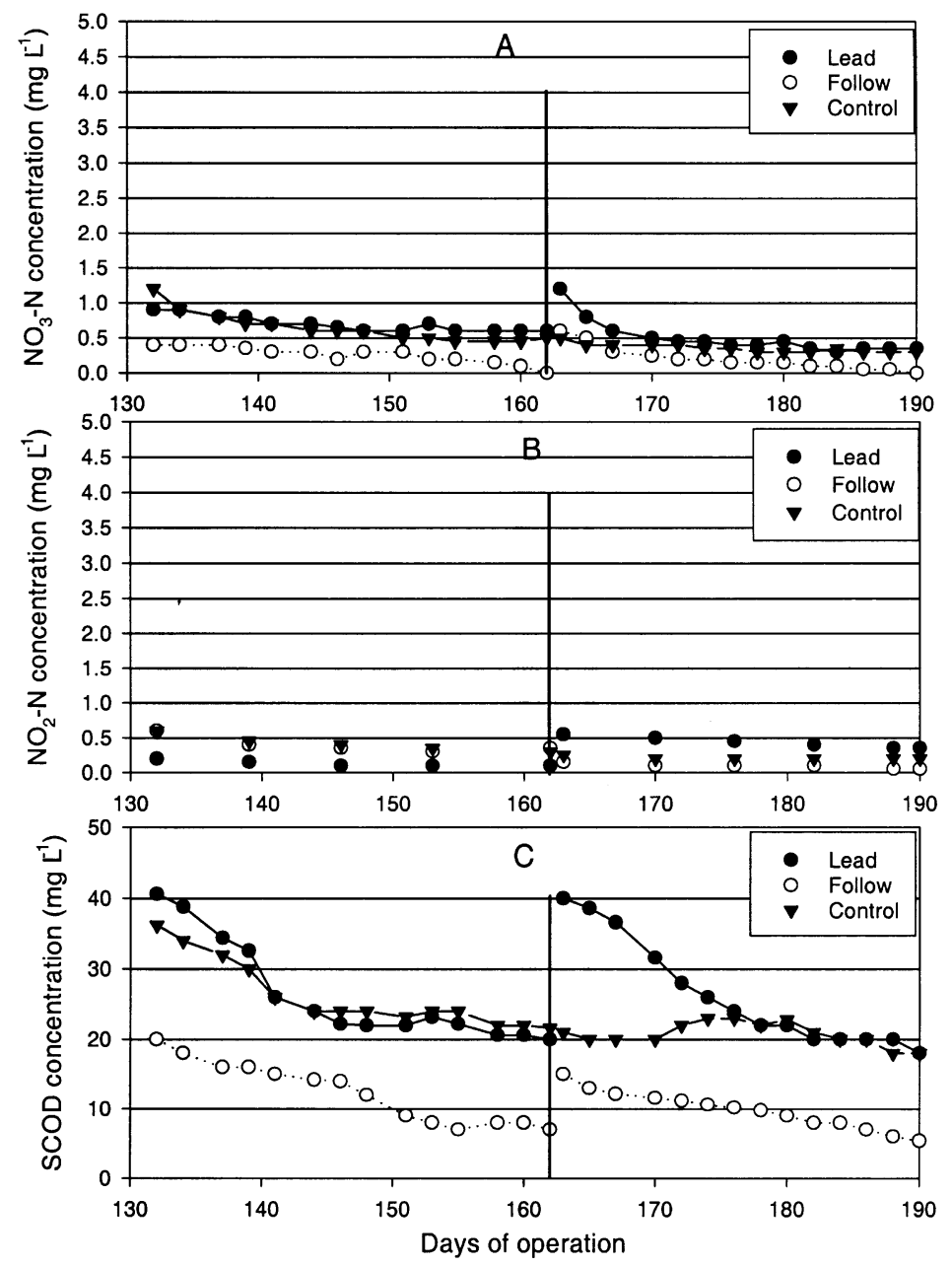

Fig. 4. Reactor effluent performance where $\mathrm{A}$ is the nitrate-nitrogen, $\mathrm{B}$ is the nitrite-nitrogen and $\mathrm{C}$ is the SCOD concentration during Phase 5. Note the flow reversal on day 162 of operation.

in the single-stage system. After flow reversal, the average SCOD concentration in the follow reactor increased slightly to $14 \mathrm{mg} \mathrm{L}^{-1}$ while the singlestage system maintained approximately $17 \mathrm{mg} \mathrm{L}^{-1}$ throughout the entire flow cycle. These results illustrate the advantages of the two-stage, reversible flow system.

During Phase 5 (HRT of $1 \mathrm{~h}$ ), the nitrate removal efficiencies in the reactor systems remained essentially the same as in previous phases. The reduction of the HRT did not appear to have a major impact on the nitrate removal efficiency. During the first flow cycle, the average effluent nitrate concentrations were 0.7 , 0.3 , and $0.6 \mathrm{mg} \mathrm{NO}_{3}^{-}-\mathrm{N} \mathrm{L}^{-1}$ in the lead, follow, and single-stage reactors, respectively (Table 2 ). Following flow reversal, the lead reactor effluent nitrate concentration temporarily increased to $1.2 \mathrm{mg} \mathrm{NO}_{3}^{-}$ $\mathrm{NL}^{-1}$, and in 1 week, decreased to approximately $0.5 \mathrm{mg} \mathrm{L}^{-1}$ (Fig. 4(A)). The effluent concentration gradually decreased to $0.4 \mathrm{mg} \mathrm{NO}_{3}^{-}-\mathrm{N} \mathrm{L}^{-1}$ by the end of flow cycle 2. The effluent nitrate concentration remained unchanged in the single-stage system with an average of $0.4 \mathrm{mg} \mathrm{NO}-\mathrm{NO}_{3}^{-1}$. Although the nitrate concentration in the single-stage system always exceeded the concentration in the follow reactor, there were minimal differences between single- and two-stage, reversible flow operation. The average nitrate removal efficiencies for flow cycle 1 and 2 exceeded $98 \%$ in all three reactors. The reversal of the flow direction appeared to have minimal long-term effect on the reversible flow system performance.

The effluent nitrite concentration was as high as $0.6 \mathrm{mg} \mathrm{NO}_{3}^{-}-\mathrm{N} \mathrm{L}^{-1}$ in the lead reactor during Phase 5. The average nitrite concentrations were $0.4,0.1$ and $0.4 \mathrm{mg} \mathrm{NO}--\mathrm{NL}^{-1}$ in the lead, follow, and single-stage reactors, respectively, during flow cycle 1. Nearly the same values were observed during flow cycle 2 (Fig. 4(B)). When compared to Phase 4 results, the nitrite concentrations increased markedly in the single-stage reactor. It appears that the decrease in the HRT from 3 to $1 \mathrm{~h}$ had a greater influence on the single-stage system than it had on the reversible flow system. 

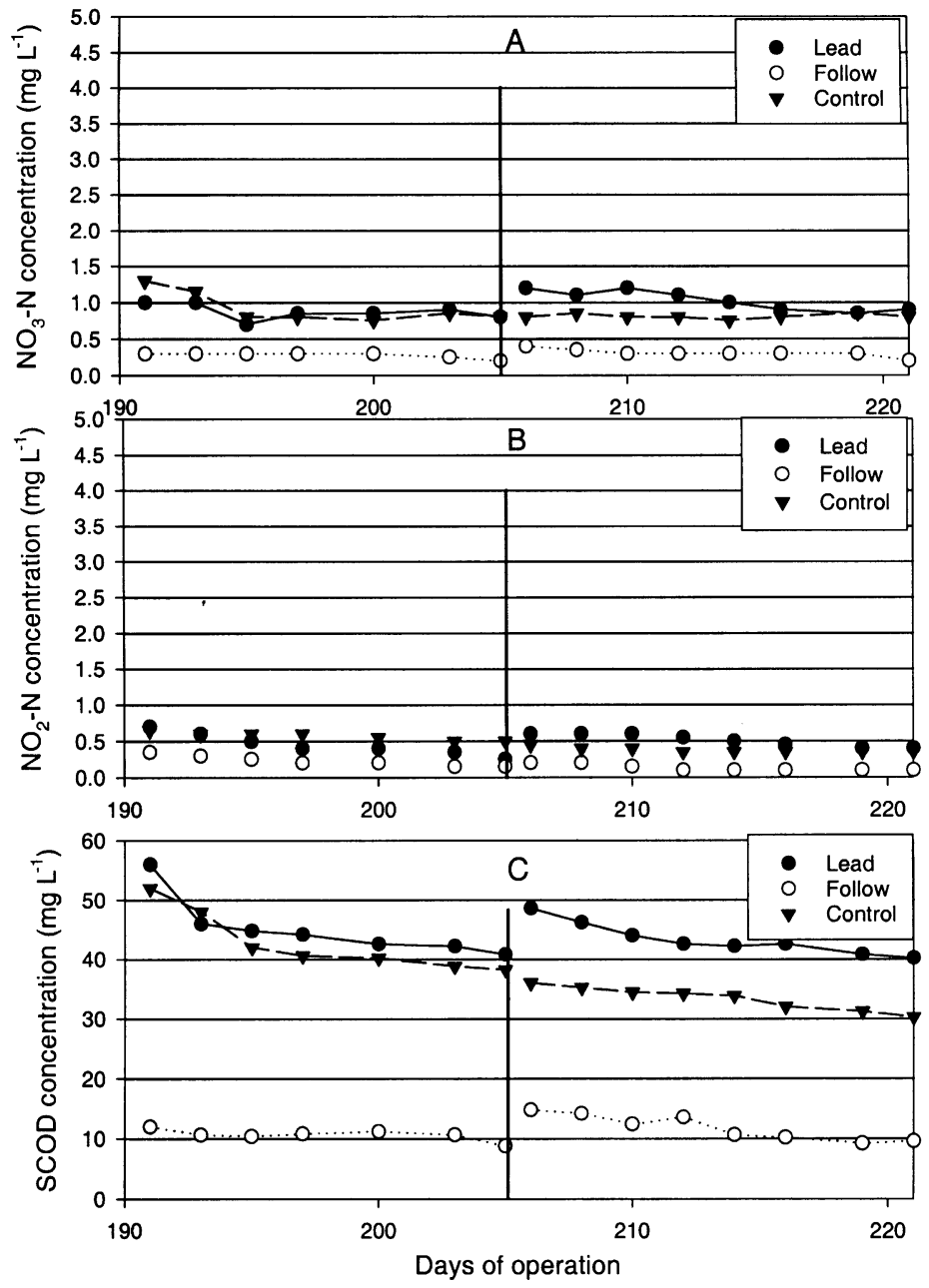

Fig. 5. Reactor effluent performance where $\mathrm{A}$ is the nitrate-nitrogen, $\mathrm{B}$ is the nitrite-nitrogen and $\mathrm{C}$ is the SCOD concentration during Phase 6. Note the flow reversal on day 205 of operation.

The average effluent SCOD concentrations during flow cycle 1 in the lead, follow, and single-stage reactors were 26,12 and $26 \mathrm{mg} \mathrm{L}^{-1}$, respectively. At the start of each flow cycle, the lead reactor effluent SCOD concentration was approximately $40 \mathrm{mg} \mathrm{L}^{-1}$ (Fig. 4(C)). After less than 2 weeks of operation the SCOD concentration of both flow periods decreased to between 20 and $25 \mathrm{mg} \mathrm{L}^{-1}$, where it remained until the end. The SCOD concentration of the follow reactor started at 20 and $15 \mathrm{mg} \mathrm{L}^{-1}$ for flow cycle 1 and 2 , respectively, and gradually decreased to approximately $6 \mathrm{mg} \mathrm{L}^{-1}$ by the end of each flow period. The SCOD concentration of the single-stage system followed a pattern that was similar to the lead reactor for flow cycle 1 . However, since there was no interruption of the flow direction, the performance of the single-stage reactor maintained a SCOD concentration of between 20 and $25 \mathrm{mg} \mathrm{L}^{-1}$.

During Phase 6 the HRT was decreased to $30 \mathrm{~min}$ from $1 \mathrm{~h}$. Once again, the change in HRT did not appear to have any adverse effects on the effluent nitrate concentration. The efficiencies remained in excess of $98 \%$ in the lead and single-stage reactors. The average effluent nitrate concentrations were 0.9 , 0.3 and $0.9 \mathrm{mg} \mathrm{NO}_{3}^{-}-\mathrm{N} \mathrm{L}^{-1}$ during the first flow cycle and $1.0,0.3$ and $0.8 \mathrm{mg} \mathrm{NO} \mathrm{NO}_{3}^{-}-\mathrm{NL}^{-1}$ during the second cycle in the lead, follow, and single-stage reactors, respectively (Table 2 ). The nitrate-nitrogen concentration of the lead and single-stage reactors during flow cycle 1 and 2 ranged between 0.5 and $1.5 \mathrm{mg} \mathrm{NO}_{3}^{-}-\mathrm{N} \mathrm{L}^{-1}$, while the follow reactor never exceeded $0.5 \mathrm{mg} \mathrm{NO}_{3}^{-}-\mathrm{N} \mathrm{L}^{-1}$ (Fig. 5(A)). Also, the flow reversal did not appear to have temporarily diminished either the lead or follow reactor performance because there were no substantial concentration increases after flow reversal. This same trend was reported by Woodbury et al. (1998) at the $30 \mathrm{~min}$ HRT. They concluded that sufficient nitrate and SCOD concentrations were retained in the lead reactor effluent to sustain the follow reactor biomass in a less dormant state.

The nitrite concentrations at the beginning of flow period one were $0.7,0.3$ and $0.7 \mathrm{mg} \mathrm{NO}_{2}^{-}-\mathrm{N} \mathrm{L}^{-1}$ in the lead, follow, and single-stage reactors, 
respectively (Fig. 5(B)). These concentrations were maintained effectively throughout both flow periods. The average nitrite concentrations were $0.5,0.1$ and $0.5 \mathrm{mg} \mathrm{NO}{ }_{2}-\mathrm{NL}^{-1}$ in the lead, follow, and singlestage reactors, respectively, at the end of the phase (Fig. 5(B)). The average nitrite concentrations in the single-stage reactor were higher than previous phases. This increase in concentrations was not noted in the two-stage, reversible flow system. The two-stage system was thus deemed more effective in maintaining low effluent nitrite concentrations than singlestage reactors.

In the beginning of Phase 6, the effluent SCOD concentrations were as high as 56 and $52 \mathrm{mg} \mathrm{L}^{-1}$ in the lead and single-stage reactors, respectively (Fig. 5(C)). After flow reversal, the average effluent SCOD concentrations were 44,12 and $34 \mathrm{mg} \mathrm{L}^{-1}$ in the lead, follow, and single-stage reactors, respectively (Fig. 5(C)). The average effluent SCOD concentration in the follow reactor was approximately $11 \mathrm{mg} \mathrm{L}^{-1}$ during both flow cycles.

The two-stage reversible flow system performance was markedly better than the single-stage system. The improvement was expressed in terms of a greater than $99 \%$ nitrate removal efficiency, equally efficient nitrite effluent concentrations and markedly improved SCOD levels than the single-stage system. These trends seemed to improve with time. The SCOD concentration in the single-stage reactor was as high as $38 \mathrm{mg} \mathrm{L}^{-1}$ at the end of the first flow cycle and decreased steadily to $30 \mathrm{mg} \mathrm{L}^{-1}$ in later periods (Fig. 5(C)). However, it should be noted that the SCOD concentration in the follow reactor was very low compared to the single-state reactor, and decreased to a final value of $10 \mathrm{mg} \mathrm{L}^{-1}$ in the second flow cycle. From these results, it was evident that the SCOD concentrations in the single-stage reactor were usually three times greater than the follow reactor, showing the relative value of the two-stage reversible flow system (Fig. 5(C)).

\section{DISCUSSION}

The results of this study have shown that twostage, reversible flow reactors can be effectively used for water denitrification, particularly at low HRT values. The reversible flow operation demonstrated considerable improvement in SCOD removal performance when compared to single-stage systems operating at the same HRT and nitrate and SCOD loading rates. The reason for this improved performance is the exposure of the first stage effluent to the high concentration of biomass in the follow stage from its previous operation as a lead unit. In addition to functioning as a polishing unit, the follow reactor also functions as a "safety net" that guards against possible performance loss in the lead unit. This, in turn, highlights the operational advantage offered by the series configuration of the reversible flow system.
Woodbury (1998) performed a series of conservative tracer studies on the reversible flow system to evaluate the volume change in biomass within the reactor as a result of flow reversal. He concluded that the biomass volume buildup in the lead reactor was approximately equivalent to the biomass volume decline in the follow reactor. The net result was the total biomass volume of the entire reactor system remained relatively constant.

After flow reversal, nitrate concentrations temporarily increased in the new lead reactor effluent. However, these concentrations were below the required limit and the total system performance was not adversely affected. Generally, after approximately 1 week of operation, the removal efficiency recovered. The reversible flow reactor system readily accepted flow reversals without loss of overall treatment efficiency. Steady-state performance of the new lead unit typically was reached in $2-3$ weeks, and the total system performance remained essentially constant.

It is evident from the nitrate removal efficiencies of both systems that the two-stage reversible flow operation was not necessarily required. This is even evident when operated at the $30 \mathrm{~min}$ HRT. However, for SCOD removal, the two-stage reversible flow system always resulted in superior performance compared to the single-stage unit. One could assume that further reduction could be attained by simply reducing the SCOD concentration in the reactor influent. However, previous research (Dahab and Sirigina, 1994; Clifford and Liu, 1993) has suggested that serious increases in nitrite concentration could be experienced if the carbon concentration is decreased below recommended stoichiometric limits.

A potential advantage of the reversible flow system is the low HRT values that can be maintained (as low as $30 \mathrm{~min}$ were used during this study). Further reduction in the HRT may be possible without major loss in nitrate removal efficiency. Woodbury (1998) operated a set of reversible flow series reactors constructed in a similar manner at a 15 min emptybed HRT. He was able to achieve an overall steadystate nitrate removal efficiency of approximately $80 \%$. He attributed the reduction in the removal efficiency to the formation of preferential flow paths within the biofilm and support media allowing for some nitrate-nitrogen to pass through the system before it could be microbially converted. It was concluded that more aggressive biomass control (including frequent wasting of excess biomass and backwashing of the reactors), along with careful optimization of the $\mathrm{C}: \mathrm{N}$ ratio in the influent, would improve the overall system performance at short HRT. Elution of extracellular polymeric substances (EPS) of the active biofilm may have been contributing to sustaining follow reactor biofilm density (Characklis and Marshall, 1990). This would limit the forced endogenous phase growth of the reactor. Low HRT values can result in considerable reduction 
in capital expenditures since smaller tanks could be used, leading to savings in capital investments in both space and total tankage volume requirements.

In the two-stage, reversible flow operation, if a system failure is observed or if impending failure is observed in the lead reactor, the flow could be switched to the follow reactor without any major anticipated loss of performance. The two-stage, reversible flow process is capable of receiving extreme shock loads without major efficiency loss.

\section{CONCLUSIONS}

Based on the results of this experimental study, the following conclusions can be made:

1. Influent nitrate concentrations were reduced at an efficiency of 98 and $99.5 \%$ in single- and two-stage denitrification reactors, respectively, when the reactors were operated at HRT values of 1.0 and $0.5 \mathrm{~h}$. Furthermore, the two-stage reversible flow system was more effective in maintaining low nitrite concentrations than the single-stage reactor when operated at the same HRT values. The reversible flow system readily accepted flow reversals without any notable efficiency loss in treatment. This performance illustrates the potential value of biodenitrification, particularly reversible flow systems, as a viable water treatment process for sustained nitrate reduction.

2. When the HRT was below $6 \mathrm{~h}$, high effluent COD concentrations in the traditional single-stage system were experienced. Additional COD removal was achieved by the reversible flow system. The overall COD removal performance of the reversible flow system was considerably higher than that in a single-stage unit operating at the same HRT. In addition, the effluent total suspended solids concentrations in the two-stage cyclic operation were consistently lower than those from the single-stage system, when both were operated at the same HRT.

3. The reversible flow system demonstrated the ability to receive extreme shock loads with little or no loss of treatment efficiency upon stage reversals. These shock loads occurred every time the flow was reversed from one reactor to the other.

4. In addition to providing added treatment efficiency, the second-stage reactor in the two-stage system functions as a standby unit that could be immediately brought into service should operational problems be encountered in one unit.

\section{REFERENCES}

American Public Health Association (APHA) (1992) Standard Methods for the Examination of Water and Wastewater, 18th ed. Washington, DC.

Blowes D. W., Robertson W. D., Ptacek C. L. and Merkley C. (1994) Removal of agricultural nitrate from tiledrainage effluent water using in-line bioreactors. J. Contam. Hydrol. 15(3), 207-221.

Bouchard D. C., Williams M. K. and Surampalli R. Y. (1992) Nitrate contamination of groundwater: sources and potential health effects. $J$. $A W W A$ 84(9), 85-90.

Characklis W. G., Marshall K. C. and McFeters G. A. (1990) The microbial cell. In Biofilms eds W. G. Characklis and K. C. Marshall pp. 142-143. Wiley, New York, NY.

Clifford D. and Liu X. (1993) Ion exchange for nitrate removal. $J$. $A W W A$ 85(4), 135-143.

Dahab M. F. and Lee Y. W. (1988) Nitrate removal from water supplies using biological denitrification. J. Water Pollut. Control Fed. 60(10), 1857-1861.

Dahab M. F. and Sirigina S. (1994) Nitrate removal from water supplies using biodenitrification and GAC-sand filter systems. Water Sci. Technol. 30(9), 133-139.

Hach Company 1992. Hach Water Analysis Handbook, 2nd ed. Hach Company, Loveland, CO.

Howerton D. E. and Young J. C. (1987) Two-stage cyclic operation of anaerobic filters. J. Water Pollut. Control Fed. 59(3), 788-794.

Hunter W. J., Follett R. F. and Cary J. W. (1997) Use of vegetable oil to remove nitrate from flowing groundwater. Trans. ASAE 40(2), 345-353.

Miháltz P., Csikor Z. and Czakó L. (1997) Performance and biofilm control of fluidized-bed bioreactors fed by high nitrate groundwater. Proceedings of the Annual Conference of the Water Environment Federation. October 18-22, Chicago, IL.

Mirvish S. S. (1991) The significance for human health of nitrate, nitrite and $n$-nitroso compounds. In Nitrate Contamination: Exposure, Consequence, and Control. Vol. 30 eds I. Bogardi and R. D. Kuzelka, NATO ASI Series G: Ecological Sciences, pp. 253-266. SpringerVerlag, New York.

Siddique M. A. and Young J. C. (1995). Denitrification using a two-stage cyclic process, Proceedings of the 68th Annual Conference of the Water Environment Federation, Miami, FL, October 21-25.

US Environmental Protection Agency (1987) Nitrate/ Nitrite: Health Advisory, Office of Drinking Water, US Environmental Protection Agency. Washington D.C., March 31.

van der Hoek J. P. and Klapwijk A. (1987) Nitrate removal from ground water. Water Res. 21(8), 989-997.

Woodbury B. L., Dahab M. F., Miháltz P. and Csikor Zs. (1998) Evaluation of reversible fixed-film static-bed biodenitrification reactors. Water Sci. Technol. 38(1), 311-318.

Woodbury B. L. (1998) Static-bed biodenitrification coupled with in-situ polishing for remediating nitratecontaminated water supplies. Ph.D. Dissertation. University of Nebraska, Lincoln, NE. 